\title{
Sodium Channel Binding
}

National Cancer Institute

\section{Source}

National Cancer Institute. Sodium Channel Binding. NCI Thesaurus. Code C40543.

A process that involves the binding of a neurotransmitter to a ligand-gated sodium

channel protein. This interaction plays a role in the regulation of signaling pathways that mediate muscle cell depolarization. 